\title{
THE DIFFERENCE IN THE DEFINITION OF SUCCESSFUL IMPLEMENTATION OF THE ICT CURRICULUM BETWEEN THE TEACHER TRAINEES, ADMINISTRATOR AND LECTURER
}

\author{
Choon Keong, Tan ${ }^{1}$ \\ Faculty of Psychology \& Education, \\ Universiti Malaysia Sabah (UMS), Malaysia. \\ (Email: cktanums@gmail.com) \\ Min Han Alvin, Auh ${ }^{2}$ \\ Faculty of Psychology \& Education, \\ Universiti Malaysia Sabah (UMS), Malaysia. \\ (Email: alvinauh@hotmail.com) \\ Kean Wah, Lee ${ }^{3}$ \\ Faculty of Education, \\ University of Nottingham Malaysia Campus, Malaysia. \\ (Email: keanwah@gmail.com)
}

Received date: 29-03-2019

Revised date: 16-06-2019

Accepted date: 10-09-2019

Published date: 12-09-2019

To cite this document: Tan, C. K., Auh, A. M. H, \& Lee, K. W. (2019). The Difference in the Definition of Successful Implementation of the ICT Curriculum between the Teacher Trainees, Administrator and Lecturer. Journal of Information System and Technology Management, 4(14), 01-17.

DOI: $10.35631 /$ jistm. 414001

\begin{abstract}
The study is a case study on a group of teacher trainees currently in their sixth semester in a teacher training college. The study investigated the implementation of subjects to prepare teacher trainees to use ICT in the classroom. The study was conducted in a teacher training college in Kota Kinabalu, Sabah. The focus in this case will be on how the teachers were trained in the college to use technology, integrate technology into their pedagogy and use technology to deliver the content of the lesson. The study utilized Trowler's (2003) implementation staircase to establish how the implementation was carried out in the teacher training institute by the lecturer in charge. The study was conducted on a group of 30 teacher trainees, a teacher training lecturer and an administrator of the institute. The data was collected via a TPACK (Technological Pedagogical Content Knowledge) survey to ascertain the teacher trainees' TPACK level. A focus group interview on the teacher trainees and lecturer was conducted to the implementation of ICT via the curriculum in the college. The data collected indicated a mismatch in the results of the implementation. The teacher trainees perceived that the implementation of the ICT curriculum is insufficient whereas the implementation of the ICT curriculum was perceived as a success by the lecturer.
\end{abstract}

Keywords: Technology, ICT, Curriculum, Teacher Education, TPACK 


\section{Introduction}

The integration of ICT (information and communications technologies) in education is common in any education system of any nation seeking to address the challenges of the $21^{\text {st }}$ Century. In addition, many developed nations in Asia are supportive of the use of ICT in education (Latchem \& Jung, 2010). The use of ICT in the classroom is paramount in preparing students for the $21^{\text {st }}$ century as well as the future work force.

As ICT is important in education, teachers should be taught how to implement ICT in the classroom. The implementation of ICT in the classroom is important as it helps with student learning in the classroom (Bingimlas, 2009). However, there are issues when it comes to ICT implementation in the classroom.

Thus, the training of teacher trainees to be able to implement ICT well in the classroom is important. This is concurred by Abuya, Admassu, Ngware, Onsomu \& Oketch (2015) who mentioned that these teacher trainees will eventually become teachers. These teachers will then be implementing ICT in the classroom for the future. As such, if these teachers are illtrained, the teaching and learning using ICT may be affected. As such, this study will focus on how the teacher trainees are trained to use ICT in the classroom. This study will also take into account the perspectives of the administrator and lecturer involved in the training of teacher trainees.

\section{Statement of the Problem}

Ambient insight (2014) stipulated that Malaysia was one of the nations with the highest growth rates in E-learning. However, one issue that could hinder the full potential of Elearning from being realized is the poor implementation of the ICT curriculum in teacher training colleges. This is seen especially with subjects or implementation that is not aligned with the needs of the teacher trainees. This is seen in curriculum and curriculum implementation in Hong Kong where $\mathrm{Hu}$ (2015) pointed out the lack of guidelines in how ICT application in the classroom should be carried out, resulting in the impediment of E-learning in the classroom.

Many studies have also pointed out the importance of teacher training in ensuring the success of ICT implementation of a particular nation. Heo (2016) pointed out the importance of ICT implementation in the college for the needs of teacher trainees, citing the new framework implemented in South Korea to have assisted the teacher trainees to better implement ICT in the classroom. Kendall (2009) cited the example of the need for pre-service teaching courses to be supplied with the appropriate infrastructure in order for the teaching and training of teacher trainees to be done to its fullest potential.

Jizat (2012) claimed that teaching training in Malaysia does expose future teachers to ICT literacy. However, teachers in Malaysia were found to prefer the use of large pieces of paper and blackboard as compared to ICT in the classroom. This suggests, according to Jizat that pre-service teachers know what ICT is but applications of these tools were not fully realized. Mat-jizat, Osman, Yahaya \& Samsudin (2016) also concurs with this, citing inadequate training in using and applying ICT related tools to spur E-learning. This is in line with Bingimlas (2009) where a review of literature pointed out a few common issues in ICT implementation for the teacher training college. These challenges include the lack of technical support, the lack of training, the lack of time and the resistance to change. In addition, some teachers in Malaysia were unwilling to implement ICT in the classroom despite being trained 
to do so. This is seen in the study by Majeed \& Yusoff (2015) who pointed out that some teachers were unwilling to do so due to the difficulties and barriers associated with ICT implementation in the secondary school classroom. These barriers include the lack of access to computers and the use of obsolete hardware. In addition, a study by Zaki \& Zahilah (2013) that compared teachers from both Malaysia and Australia attributed the resistance towards ICT use by some teachers to the training of using ICT without taking into account the teachers' self-efficacy. As such, despite receiving adequate training the teachers were not confident or comfortable using ICT in the classroom.

To be more specific with ICT implementation in teacher training, two aspects would be focused on, one is the definition of successful ICT implementation and the other on the guidance by the teacher trainer in guiding ICT implementation in the classroom. Studies such as those by Mugisha (2007) pointed out the importance of guidance from the curriculum in terms of how to implement ICT in the classroom. This points to a likely focus on the content knowledge instead of application in the classroom and would lead to different points of view of what success means in the classroom. This is seen in studies by Sheard \& Carbone (2007) as well as Waycott, Bennett, Kennedy, Dalgarno \& Gray (2010) whereby studies conducted in both contexts indicated the lecturer pointing out successful ICT implementation by the students but the students felt that training was lacking and were not able to use ICT in the classroom effectively. With that, this study aims to address the gap of how the difference in definition with regards to successful implementation of ICT in the classroom can affect the teacher trainees' ability to utilize ICT to spur E-learning.

\section{Objectives of the Study}

This study aims to investigate how:

i) Teacher training guides future teachers to utilize ICT to spur E-learning in the classroom.

ii) The lecturer's and administrator's definition of success similar/different from students'?

\section{Research Questions}

The research questions of the study are as follow:

i) How does teacher training guide future teachers to utilize ICT to spur E-learning?

ii) How is the lecturer's and administrator's definition of success similar/different from the students'?

\section{Significance of the study}

This study is significant as curriculum implementation is one of the issues faced. As there is a myriad of reasons attributed to curriculum implementation, one such factor can be linked to how both lecturer and student define successful ICT implementation. Results from the study can be used to address how ICT curriculum is being implemented. In addition, the results for this study can be used to better inform how ICT application in classroom can be better carried out, further equipping future teachers in better implementing ICT in the classroom. Aside from that, the incorporation of the administrator's point of view will help future policymakers formulate policies that would better aid ICT implementation in the classroom.

\section{Review of Literature}

This section will expound on the theories and frameworks that will be utilized in the study. This includes the TPACK (Technological Pedagogical Content Knowledge) learning theory as well as Trowler's (2003) implementation staircase. This section will describe the theories and models that will be utilized in this study. 


\section{TPACK Learning Theory in The Classroom}

TPACK stands for Technological Pedagogical Content Knowledge. The TPACK learning theory has been seen in many studies to be a form of a benchmark to ascertain the full implementation and integration of ICT in the classroom. An example is seen in the study by Dong, Chai, Sang, Koh \& Tsai (2015) pointed out that the use of TPACK can be beneficial to teacher education, educational technology and ICT integration in the classroom. More specifically, it is used as a way to gauge integration of ICT in the classroom. In addition, studies also show the use of TPACK as a way for teachers to develop a form of link or connection between technology, content and pedagogical knowledge.

TPACK was chosen for this study due to its use and how that fits the objectives of this study. Another framework that can be potentially used for this study and is similar to TPACK, is the Substitution, Augmentation, Modification and Redefinition (SAMR) framework. Pamuk (2012) posited that the use of TPACK and SAMR have its differences but are used to guide the assessment, planning and use of technology in the classroom.

This study will utilize the TPACK framework due to the objective of the study to examine if technology is integrated in a pedagogically appropriate manner to support learning (Khan, 2014). In addition, the study by Chai, Koh, Tsai \& Tan (2011) pointed out the use of TPACK to be used for course design evaluation for pre-service and in-service teachers for the purpose of integration in the classroom. In addition, the use of SAMR is used to assess change when technology is incorporated and this point to a more to an evaluation of change due to the use of technology (Myers, 2014). As such, this does not investigate how the use of ICT can be used to spur E-learning in the classroom.

\section{Trowler's (2003) Implementation Staircase Framework and Vedung's (1998) Taxonomy on Policy Instruments}

Trowler's (2003) implementation staircase framework will be used in tandem with Vedung's (1998) taxonomy on policy instruments to investigate the implementation of ICT in the teacher training institute. Trowler's (2003) implementation staircase was modified to fit the context of the study. Since this study will only take into account the administrators and lecturers involved in this study, the other components of the staircase will not be taken into account. This was done in the study by Varga-Atkins (2016) who modified the implementation staircase to fit the objectives of the study. The combination of both frameworks is done in order to provide a more extensive explanation on certain aspects of the study. For example, the implementation aspect can be investigated using Trowler's implementation staircase framework. In the context of the study, how do the teacher trainees acquire techniques and methods on incorporating ICT in the classroom which is being carried out by the lecturers of the higher learning institutions. The implementation staircase would provide an insight of how the curriculum is implemented.

This would be used in tandem with Trowler's implementation staircase to investigate the effects between and within the system to ascertain how the curriculum on ICT contributes to the teacher trainees being equipped in the classroom. This will provide a good overview of the success or failure of the curriculum implementation. This will be displayed in the Table 1 below: 
Table 1: Vedung's (1998) Taxonomy on Policy Instruments for The Context of This Study

\begin{tabular}{ll}
\hline \multicolumn{1}{c}{ Classification } & \multicolumn{1}{c}{ Explanation } \\
\hline Regulations & $\begin{array}{l}\text { The study aims to use this classification to ascertain what } \\
\text { regulations/step by step and decrees encourages or prompts } \\
\text { certain actions. }\end{array}$ \\
\hline Economic means & $\begin{array}{l}\text { This study will use this classification to ascertain what the } \\
\text { particular incentives are provided to the trainers, institutions } \\
\text { or trainees. }\end{array}$ \\
\hline Information & $\begin{array}{l}\text { This study will use this classification to ascertain the moral } \\
\text { justification and reasons behind the curriculum implemented. }\end{array}$ \\
\hline
\end{tabular}

As such, with both frameworks used in tandem, this should provide a good overview as to how policies are interpreted from one staircase to the other and how are these policies implemented and sustained.

The incorporation of two frameworks will be illustrated in Figure 1 below:

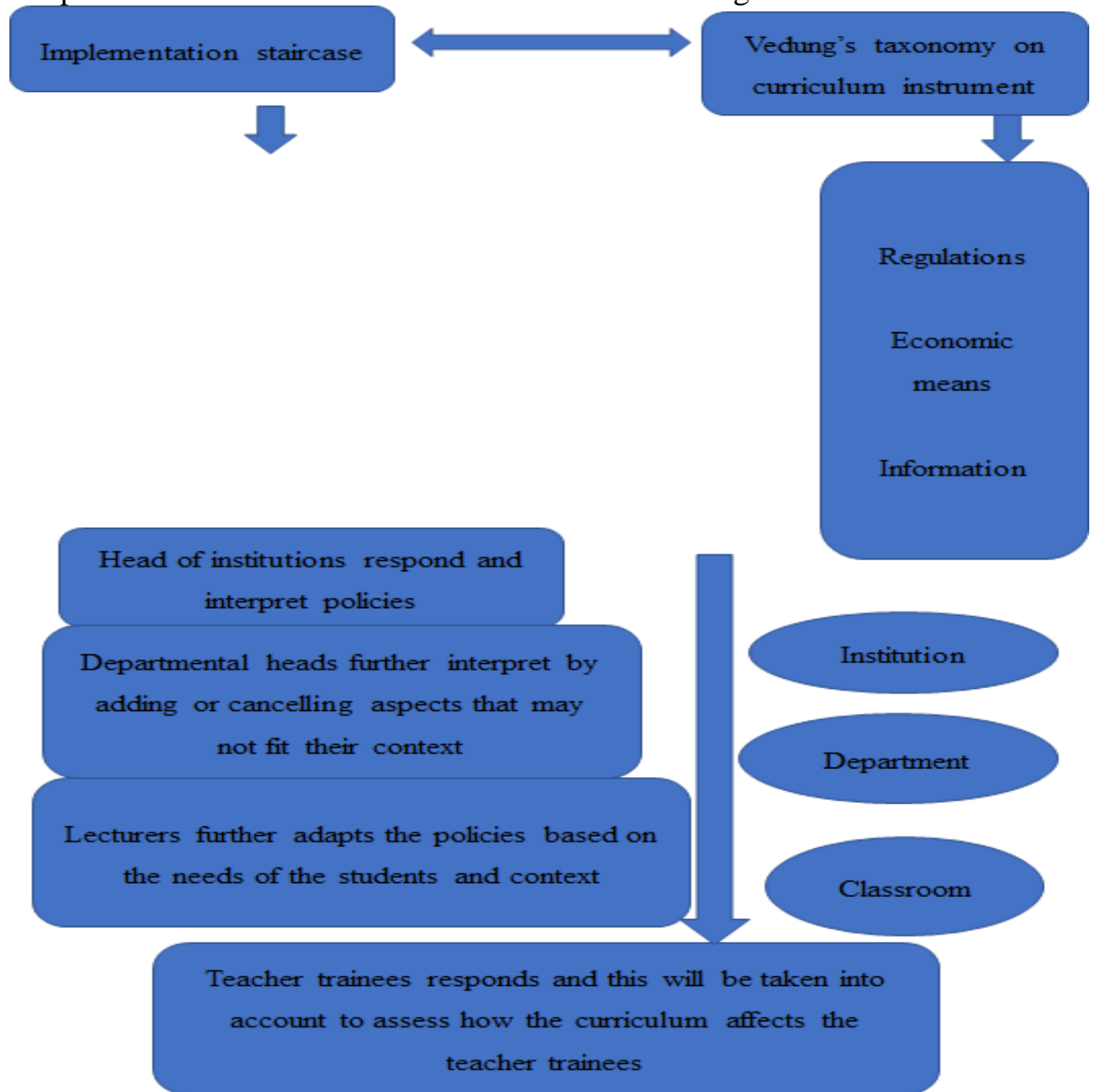

Figure 1: Trowler (2003) Implementation Staircase Supplemented with Vedung's Taxonomy on Curriculum Instruments 
The TPACK was used in the study to investigate the teacher trainees' acceptance towards the use of ICT. In order to investigate the lecturer's and administrator's point of view on ICT implementation, the implementation staircase was used in tandem with Vedung's taxonomy on policy instruments.

\section{Methodology of the Study}

This section will discuss about the methodology that will be used in this study. Specifically, this chapter will cover the research design that will be utilized in this study, covering aspects related to study. In addition, the population and sampling that will be used in this study will be expounded.

\section{Research Design}

This study will be of a mixed method design whereby Creswell (2012) pointed out that a mixed method design is a combination of both quantitative and qualitative design. In addition, Fraenkel, Wallen and Hyun (2012) pointed out that the use of a mixed method design can help explain the variables between both quantitative and qualitative design. Fraenkel, Wallen and Hyun pointed out that there are different types of mixed method design. However, for this study, the specific type of mixed method design is the triangulation design whereby both quantitative and qualitative design are of equal importance and can be used to ascertain the research questions set forth in the study.

With the use of the triangulation design, the qualitative aspect of the design will be of the interview. In addition, this study's primary focus is to investigate how the difference in definition for successful implementation affects the implementation of the ICT curriculum in the teacher training college. However, this study will not discount the use of quantitative elements and as such will be utilizing a survey to ascertain the teacher trainees TPACK levels. This will be later supplemented with an interview as well to ascertain the conclusion to the research questions.

\section{Population and Sampling}

The study will use a purposive sampling method to select the respondents of this study. The study will consist of 40 pre-service teachers who have just returned from their industrial training or also known as practicum. The 40 pre-service teachers will be taken from a teacher training college in Kota Kinabalu, Sabah. These pre-service teachers will be referred to as respondents for the purpose of this study. These pre-service teachers are selected purposefully as this study requires the respondents to have at least some internship or practicum experience. As most institutions may have a number of students, this study will only be focusing on those who have been to school for an extended amount of time.

The respondents selected for this study is representative of the data as Creswell (2012) pointed out a number of 30 to 40 samples to be acceptable in a qualitative study. However, Fraenkel, Wallen \& Hyun (2012) mentioned that the importance is not with the number but of the hierarchy of power where a certain curriculum is implemented from the top down. Fraenkel, Wallen \& Hyun pointed that an interview of the heads of departments, teachers and implementers of a curriculum will suffice despite not interviewing the students involved in the curriculum. As such, the sample selection is justified as the study will consist also of one lecturer to provide a better understanding to the results obtained. The lecturer involved in this study teaches ICT and thus can provide a good insight into the research objectives set forth. In addition, an administrator of the institution will also be interviewed. 


\section{Instrumentation}

The data collection methods for this study consist of a survey and an interview. This will be utilized to investigate and triangulate different sets of data to answer the research questions.

\section{Survey}

The survey and interview will be designed according to TPACK was chosen as a framework for Nordin's (2014) study. However, a few modifications will be made to the TPACK survey from Nordin's study. The survey will utilize a four-point Likert scale instead of a five-point Likert scale and this is deemed acceptable by Lozano, García-Cueto \& Muñiz (2008) who pointed out that the acceptability of Likert scales range between a four-point to a seven-point Likert scale. The use of a four point Likert scale and calculated via Cronbach alpha has been done in studies such as those by Terrace (2003). The questionnaire will be distributed via Google Forms.

The TPACK survey will be distributed to all of the pre-service teachers in the study via Google forms. The TPACK survey was modified from a five-point Likert scale to a four point Likert scale. This is done in order to avoid students from selecting the neutral stance over the questions. This is deemed as acceptable by Lozano, Garcia-Cueto \& Muniz (2008). The survey was used to assess the students' TPACK levels and to provide a basis for the follow-up interview questions. From the TPACK survey, the focus group interview will investigate the extent of the success of curriculum in guiding the implementation of ICT in the classroom.

The questions for technological pedagogical content knowledge will focus on the combination of all technology, content and pedagogical aspects in their classroom. The questions will focus on how teacher training courses has contributed to their TPACK levels. To support and confirm the findings, interview questions from the implementation staircase will be used to investigate the process of the implementation. This will be elaborated in the section below.

\section{Interview}

The interview is divided into two portions; one is adapted from the TPACK survey while the other consists of the questions from the implementation staircase. The interview questions for the teacher trainees will be modified from the TPACK survey.

In addition, other respondents such as the institute's lecturer in charge of ICT will be interviewed to investigate how the implementation of ICT in the teacher training college was carried out. The implementation staircase is adapted from Mofarreh \& Ibrahim's (2016) interview questions that was designed based on the implementation staircase. Furthermore, an administrator will also be interviewed to further investigate the administrator's point of view on this. Since the implementation staircase from Mofarreh \& Ibrahim's study were looking at other aspects of implementation, some questions related to Vedung's (1998) taxonomy on policy instruments were added to investigate how policy was implemented from the perspective of economic means, regulation and information. These perspectives consist of the infrastructure, the mandates and the training given to ensure that ICT can be implemented and taught successfully to the teacher trainees. 


\section{Data Analysis Method}

The interview will be adapted from Mofarreh \& Ibrahim (2016) with the incorporation of questions that take into account the implementation staircase and can be used to confirm how curriculum is implemented from the top implementers down to the students.

The TPACK survey will be analyzed in a quantitative manner. The responses will be analyzed via mean scores and will only be done so to addresses the extent to which teacher training has helped the teacher trainees' TPACK. The TPACK survey will be modified to incorporate a qualitative component. This is to prompt the participants to further elaborate on their technological pedagogical content knowledge. The participants will be called for an interview and will be questioned further on the interview with regards to how the curriculum has helped provide the necessary content knowledge for ICT implementation in the classroom. Comparatively, Nordin's (2014) implemented a similar method in another study, utilizing a focus group interview upon the completion of the survey. This is to further provide confirmation to the scores obtained in the survey.

The transcript of the interview will be analyzed via assigning different themes and categories to the data garnered from the interview (Creswell, 2012). Creswell also pointed out the themes from an interview are based on the themes specific to the context of the research. This is to provide context and meaning to the responses obtained in the interview.

\section{Results}

The results section will be divided into two sections, first section will consist of the data from the survey while the second section will consist of results and statements garnered from the TPACK interview and implementation staircase interview conducted throughout the study:

\section{TPACK Survey Results}

The results from the TPACK survey will be divided into different sections. The first section consists of the technological knowledge which investigates the teacher trainees' knowledge on technology, the overall mean score obtained was 2.69 out of the Likert scale of 4 , suggesting many who perceive the lack of knowledge on technology. In terms of content knowledge, the overall content knowledge score was 3.114, indicating that most of the teacher trainees are confident with the content that they are teaching and have a rather good knowledge on what they are teaching.

In terms of pedagogical knowledge, the overall pedagogical knowledge score was 3.088, indicating that most of the teacher trainees are confident with the methods they employ in teaching a class. In terms of pedagogical content knowledge, the overall pedagogical content knowledge score was 2.96, indicating that most of the teacher trainees are confident with how knowledge and strategy were employed in teaching.

In terms of technological content knowledge, the overall technological content knowledge score was 3.05, indicating that most of the teacher trainees are confident with how technology and what was taught in the classroom were successfully integrated. In terms of technological pedagogical knowledge, the overall technological pedagogical knowledge score was 3.16, indicating that most of the teacher trainees are confident with how technology and what was taught in the classroom were successfully integrated.

In terms of technological pedagogical content knowledge, the overall technological pedagogical content knowledge score was 3.05, indicating that most of the teacher trainees 
are confident with how technology, content of the lesson as well as pedagogical skills were integrated well. The results of the survey are illustrated in Figure 2 below.

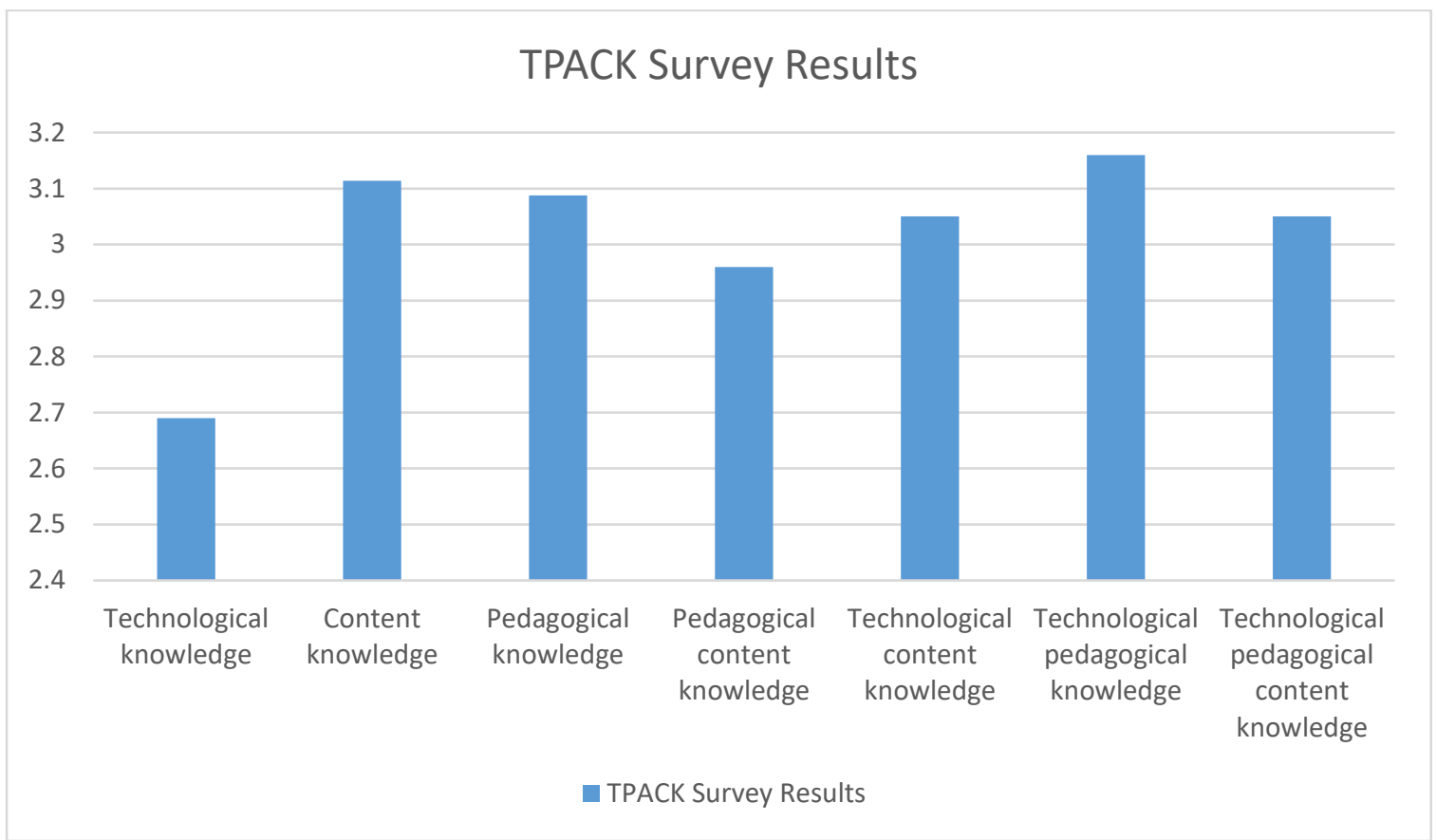

Figure 2: TPACK Survey Results

\section{TPACK Interview Results}

The section below consists of the interview results obtained using TPACK.

\section{Technological Knowledge}

The interview questions for this study will be divided via the categories as stipulated in the TPACK survey. The first section is technological knowledge where the respondents provided a general response that the technological knowledge obtained was from the internet and from family and not from the courses taught in the teacher training college.

This is seen in the following statements by the respondents:

"... learnt how to solve technical problems in technology from friends and cousins..." (R3TK1)

"...the courses on ICT did not teach me anything on how to use ICT..." (R6TK6)

“...technology taught in the teacher training course was not relevant...” (R2TK2)

The overall results indicated that teacher training did not provide the respondents with any relevant guidance that contributed to their technological knowledge.

\section{Content Knowledge}

The responses for the content knowledge section are seen below:

“...learnt much in teacher training in terms of management and how to handle the classroom..."(R3CK1)

"Yes, I have learnt much in terms of strategies and theories in teaching." (R1CK2)

"Not able to make learning less complex because I tend to keep explaining to the students who don't understand." (R9CK4) 
"Yes, I get to teach my class how to apply and how to speak English." (R3CK5)

Based on the responses above, the respondents in general perceive that their content knowledge is adequate and are able to teach the students of their class the content well. The content in this case refers to the English primary curriculum.

\section{Pedagogical Knowledge}

In terms of pedagogical knowledge, the responses of the respondents are displayed below:

"...taught how to design a lesson plan in the teacher training course and we know what to do step by step..." (R11 PK 1)

“...courses such as linking theory to practice has helped me in knowing what to do in the class sometimes." (R8PK 2)

"...learning and the learner taught me about the things that I should and should not do in the classroom." (R5PK 5)

In general, the respondents perceive that pedagogical knowledge is one thing that they have benefitted them a lot in the teacher training course. They were able to name more than one course that has contributed to this.

\section{Pedagogical Content Knowledge}

In terms of pedagogical content knowledge, the responses of the respondents are displayed below:

“...difficult to assign content that fits teaching...” (R12 PCK1)

"...not very confident in teaching..." (R3 PCK2)

"I learnt mainly through experience, not exactly from any course in IPG." (R7 PCK3)

"Some courses such as language description and development does help." (R4 PCK4)

"...learnt mainly from experience and do so by varying activities..." (R8 PCK5)

In general, the respondents mentioned that their ability to perform well in the pedagogical content knowledge section is due to experience with some limited help from certain courses in teacher training college.

\section{Technological Content Knowledge}

In terms of technological content knowledge, the responses of the respondents are displayed below:

"...through mentoring sessions and common sense..." (R13 TCK1)

"...forced to explore by ourselves, not specified in any course.." (R10 TCK1)

"...forced to explore as part of an assignment but were never taught specifically how to use it..." (R5 TCK2)

“...apps such as Kahoot and quizlet were obtained from mentoring and extra-curricular activities..." (R8 TCK5)

In this section, respondents attributed the knowledge on technology and content to mainly extra-curricular and mentoring sessions of the course. No specific course was mentioned to have taught the respondents methods or guided the respondents towards implementing technology in the teaching of specific content in the classroom. 


\section{Technological Pedagogical Knowledge}

In terms of technological pedagogical knowledge, the responses of the respondents are displayed below:

“...choose the correct technology from the google playstore..." (R5 TPK 1)

"...choose it from the internet..." (R7 TPK 1)

"...not really taught or know how to choose, no internet and computers..." (R3 TPK2)

"...not really taught how to teach but was introduced to technology in the ICT course..." (RI $T P K 3)$

All in all, the respondents responded that self-experimentation and experience were ways of how technology was applied in the pedagogy of the class. However, some minor attribution to the education technology course has prompted the use of technology in pedagogy either via the content of the course or the assignment.

\section{Technological Pedagogical Content Knowledge}

In terms of technological pedagogical content knowledge, the responses of the respondents are displayed below:

"...learnt mainly from the modules in school, no guidelines from training." (R2 TPACK1)

"...had to google and find out from the internet..." (R6 TPACK1)

"...learnt from English from young learners, which is not part of the curriculum." (R4 TPACK5)

“...some courses do teach us LMS like Schoology.” (R2 TPACK5)

Overall, the respondents found the lack of guidelines and infrastructure to be a deterrent to the integration of content, technology and pedagogy in the classroom. In addition, the lack of explicit guidelines and requirement has made it unnecessary for the implementation of ICT to support content and pedagogy in the classroom.

\section{Implementation Staircase Interview with Lecturer Results}

The implementation staircase interview was conducted on the lecturer in charge of ICT in the teacher training institute. The results are displayed according to the questions set forth below:

Table 2: Implementation Staircase Interview with Lecturer Results

\begin{tabular}{|c|c|c|}
\hline No & Questions & Response \\
\hline 1. & $\begin{array}{l}\text { How does your institute implement a } \\
\text { curriculum provided by the Ministry? }\end{array}$ & $\begin{array}{l}\text { No one software, from the common ones to } \\
\text { the high end one, no limitation by the } \\
\text { ministry, Use of a course outline, to guide } \\
\text { the implementation, }\end{array}$ \\
\hline & $\begin{array}{l}\text { Is the use of technology incorporated } \\
\text { into all of your school policies for each } \\
\text { subject area? }\end{array}$ & Everything including TESL \\
\hline 3. & $\begin{array}{l}\text { What is your role in the implementation } \\
\text { process? }\end{array}$ & $\begin{array}{l}\text { Exams/assignments questions are set by the } \\
\text { lecturer, so software is determined by the } \\
\text { lecturer. Exposures and step by step are } \\
\text { given by the lecturer in class and not just in } \\
\text { their practicum only providing them } \\
\text { guidance, giving them a storyboard }\end{array}$ \\
\hline
\end{tabular}


curriculum to spur learning in Higher learning institutions? across, getting the students to understand concepts such as pictures or things that they may not understand.

5. Is there an incentive in implementing It's a need and in a way part of regulation. ICT curriculum?

6. How does a manager of the institute Leaders encourage it, but not much /main department/lecturer of ICT support. However, students are committed implement the ICT curriculum?
7. Are you satisfied with ICT curriculum in teacher training institute? If yes how? If no why?

\begin{tabular}{l}
\hline Do you think your teacher \\
trainees/lecturers are satisfied with \\
implementation of the ICT curriculum? \\
And how would teacher \\
trainees/lecturers satisfaction be \\
measured? Do you ask for teacher \\
trainees/lecturers feedback? How? \\
\hline $9 . \quad$ To what extent do you think ICT \\
curriculum in teacher training institutes \\
is well designed and does it provide \\
tangible results? \\
\hline 10. In your opinion, what factors facilitate \\
the implementation of ICT curriculum \\
in teacher training institutes? \\
\hline 11. In your opinion, what factors that hinder \\
the implementation of ICT curriculum \\
in teacher training institutes? What do \\
you suggest overcoming these \\
obstacles?
\end{tabular}

12 Do cultural factors hinder the implementation of ICT curriculum in teacher training institutes? If so, can you identify some of these cultural factors? To what extent does it support or hinder the implementation of ICT curriculum in teacher training institutes?

13. What are the major requirements for successful implementation of ICT curriculum in teacher training institutes?

\section{Implementation Staircase Interview with Administrator Results}

The implementation staircase interview was conducted on the lecturer in charge of ICT in the teacher training institute. The results are displayed according to the questions set forth below: 
Table 3: Implementation Staircase Interview with Administrator Results

\begin{tabular}{|c|c|c|}
\hline No & Questions & Response \\
\hline 1. & $\begin{array}{l}\text { Is there an implementation plan for the } \\
\text { ICT education for teacher training } \\
\text { institutes? }\end{array}$ & $\begin{array}{l}\text { Not exactly... Some collaboration with } \\
\text { other colleges were done and other forms } \\
\text { of implementation include research } \\
\text { conferences. }\end{array}$ \\
\hline 2. & $\begin{array}{l}\text { Which subject areas in teacher training } \\
\text { institutes does it cover? Does it cover } \\
\text { the TESL subjects? }\end{array}$ & $\begin{array}{l}\text { Every subject, especially TESL } \\
\text { education and } \\
\text { implementation in the classroom. }\end{array}$ \\
\hline 3. & $\begin{array}{l}\text { Is there a mechanism for evaluating } \\
\text { the implementation of ICT education } \\
\text { in teacher training institute? }\end{array}$ & $\begin{array}{l}\text { No assessment, just the use of talent review } \\
\text { to review the lecturers but not the student. }\end{array}$ \\
\hline 4. & $\begin{array}{l}\text { What is your role in the } \\
\text { implementation process? }\end{array}$ & $\begin{array}{l}\text { Implementing the talent review on the } \\
\text { lecturer to ensure ICT implementation in } \\
\text { the classroom. }\end{array}$ \\
\hline 5. & $\begin{array}{l}\text { Is there an incentive in implementing } \\
\text { ICT policies? }\end{array}$ & $\begin{array}{l}\text { No motivation for implementing ICT in the } \\
\text { classroom. }\end{array}$ \\
\hline 6. & $\begin{array}{l}\text { To what extent do you think ICT } \\
\text { education in teacher training institutes } \\
\text { is well designed and does it provide } \\
\text { tangible results? }\end{array}$ & $\begin{array}{l}\text { Well implemented in practicum especially } \\
\text { when the trainees search for ideas to } \\
\text { implement ICT in the classroom. This is } \\
\text { seen in good reviews from the headmasters }\end{array}$ \\
\hline 7. & $\begin{array}{l}\text { In your opinion, what factors facilitate } \\
\text { the implementation of ICT education } \\
\text { in teacher training institutes? }\end{array}$ & $\begin{array}{l}\text { Curriculum is a key factor and the teaching } \\
\text { of the lecturers. Curriculum and the teacher } \\
\text { in schools too. Theories have to be new } \\
\text { and updated. }\end{array}$ \\
\hline 8. & $\begin{array}{l}\text { In your opinion, what factors that } \\
\text { hinder the implementation of ICT in } \\
\text { Teacher training institutes? What do } \\
\text { you suggest overcoming these } \\
\text { obstacles? }\end{array}$ & $\begin{array}{l}\text { No internet in schools but in IPG, most } \\
\text { students have their own internet. }\end{array}$ \\
\hline 9. & $\begin{array}{l}\text { Do cultural factors hinder the } \\
\text { implementation of ICT education in } \\
\text { teacher training institutes? If so, can } \\
\text { you identify some of these cultural } \\
\text { factors? To what extent does it support } \\
\text { or hinder the implementation of ICT } \\
\text { education in teacher training } \\
\text { institutes? }\end{array}$ & $\begin{array}{l}\text { Attitude, since no internet so most people } \\
\text { feel like they don't have to use it, }\end{array}$ \\
\hline 10. & $\begin{array}{l}\text { What are the major requirements for } \\
\text { successful implementation of ICT } \\
\text { education in teacher training } \\
\text { institutes? }\end{array}$ & Internet and google \\
\hline
\end{tabular}

\section{Discussions}

Based on the findings of the study, the findings were divided based on the research questions of the study. 


\section{How Is the Lecturer's and Administrator's Definition of Success Similar/Different from The Students'?}

In the interview for both lecturers and trainees, the lecturer pointed out that ICT implementation by trainees are successful as the assignments are carried out well, the lecturer further pointed out that the teacher trainees were able to carry out ICT implementation in the classroom via assignments well. In addition, the lecturer further pointed out that guidance was provided, indicating that guidance is specific to providing the trainees an idea of how the implementation process should be like. The administrator also pointed out good reviews by the headmasters of the school, indicating those as a measure of successful implementation of the ICT curriculum.

The trainees pointed out a different point of view, indicating that it can be difficult to find materials on how to implement ICT well in the classroom. The trainees pointed out that despite guidance given, more guidance would be preferred as the assignment does not prepare for ICT implementation in a real classroom context.

The differences found here can be attributed to the TPACK learning theory where it is likely the focus of the curriculum and lecturer is more on the technology knowledge (TK) and Technology pedagogical knowledge (TPK). The trainees are perhaps finding it difficult to implement ICT in the classroom as they may find it difficult in helping the students in the classroom learn better and more efficiently via ICT. This is seen in the interview with regards to the trainees' pedagogical content knowledge (PCK) and technology.

However, lecturer, administrator and trainees concur that there is a lack of adequate facilities, infrastructure and support from administrators in implementing ICT in the classroom. This is seen in the teacher trainees' TPACK interview as well as the interview with the lecturer. With both lecturer and teacher trainees pointed out different and similar definitions of ICT implementation in the classroom, it is important for curriculum assessments to take into account the needs of the teacher trainees. After all, the teacher trainees are the product of the curriculum and as the teacher trainees are quite aware of their needs, a review should be done to address those needs. Furthermore, constant feedback from the lecturer, teacher trainees as well as schools should be incorporated to ensure that ICT implementation in the classroom is carried out successfully.

\section{How Does Teacher Training Guide Future Teachers to Utilize ICT to Spur E- Learning?}

Teacher training guides future teachers to utilize ICT to spur E-learning via the guidance provided by the lecturer. This is seen in the interview of both the lecturer and the teacher trainees where the lecturer pointed out guidance to have been provided in training for ICT use. The teacher trainees indicated that guidance were given by some lecturers on how on to implement ICT in the classroom, however it was of other non-ICT related courses in which the lecturer in charge implemented ICT in the teaching process.

The lecturer also deemed that the teacher trainees were able to successfully implement ICT in the classroom to spur E-learning from the practicum courses, stating that many school administrators have given positive comments towards the trainees' ability to implement ICT in the classroom. The interview with the lecturer also pointed to the assessment done in courses and practicum where ICT implementation in the classroom was evaluated. This has spurred the students to be more willing to implement ICT in the classroom. The teacher trainees concur with this, citing a need to implement ICT in the classroom. However, the 
challenges mentioned include the lack of knowledge on how to implement technology effectively. This could be likely due to the trainees being assessed only with their technology knowledge (TK) and Technology pedagogical knowledge (TPK) However, in order for TPACK's successful implementation, the assessment should take this into account and provide better guidance. This can also be applied in the trainees' practicum and assignments where more aspects of ICT implementation should be assessed in order for the lecturer to better guide the trainees in implementing ICT in the classroom.

Another issue that was frequently brought up by the lecturer and teacher trainees point to the lack of infrastructure for ICT implementation in the classroom. This has resulted in the trainees preferring conventional whiteboard and paper methods. The lack of infrastructure is a concern; however, the curriculum of the teacher training institute could include methods that can guide the implementation of ICT even where infrastructure for ICT implementation is lacking. This is especially the case for most rural areas in the country where internet and ICT infrastructure is lacking (Alias, DeWitt, Siraj, Rahman, Gelamdin \& Rauf, 2014).

In conclusion, teacher training does help guide the teacher trainees in implementing ICT in the classroom. However, when evaluated with TPACK, teacher trainees may have good knowledge on technology (TK) and being able to apply technology in the classroom to a certain extent (TPK), however, what is lacking is the ability to implement technology, incorporating content and pedagogy. As such future curriculum and practicum can place a further emphasis on this in order for teacher trainees to implement ICT in the classroom more effectively. Furthermore, the lack of appropriate infrastructure may also hinder ICT implementation which is a point that both lecturer and teacher trainee share, stating that it does hinder the instruction of ICT implementation.

\section{Conclusion}

The curriculum implemented in the teacher training institute is essential in encouraging the use of ICT in the classroom. Based on the study conducted, the focus should not only be on encouraging the implementation of ICT based on technology knowledge use in the classroom but how it can be implemented in the classroom as well. Furthermore, the lack of proper infrastructure and assessment could likely affect the future implementation of ICT in the classroom as the guidance needed to effectively build the teacher trainees' TPACK is lacking. In addition, both lecturer and teacher trainees' definition on successful ICT implementation in the classroom should be aligned to equip the teachers in their future classroom practices. A follow up study should investigate how curriculum can be better implemented to ensure how the curriculum can better increase the teacher trainees' TPACK levels.

\section{References}

Alias, N., DeWitt, D., Siraj, S., Rahman, M. N. A., Gelamdin, R. B., \& Rauf, R. A. A. (2014). Implementation of Ptechls Modules in Malaysian Secondary School: A Needs Analysis. Malaysian Online Journal of Educational Technology, 2(1), 30-35.

Ambient Insight. (2014, September). Ambient Insight Regional Report: The 2013-2018 Asia Self-paced eLearning Market. Ambient Insight.

Abuya, B. A., Admassu, K., Ngware, M., Onsomu, E. O., \& Oketch, M. (2015). Free primary education and implementation in Kenya: The role of primary school teachers in addressing the policy gap. Sage Open, 5(1), 2158244015571488.

Bingimlas, K. A. (2009). Barriers to the Successful Integration of ICT in Teaching and Learning Environments: A Review of the Literature. Eurasia Journal of Mathematics, Science \& Technology Education, 5(3), 235-245. 
Chai, C. S., Koh, J. H. L., Tsai, C.-C., \& Tan, L. L. W. (2011). Modeling primary school preservice teachers' Technological Pedagogical Content Knowledge (TPACK) for meaningful learning with information and communication technology (ICT). Computers \& Education, 57(1), $1184-1193$. http://doi.org/10.1016/j.compedu.2011.01.007

Creswell, J. W. (2012). Educational research: Planning, conducting, and evaluating quantitative (pp. 146-166). Upper Saddle River, NJ: Prentice Hall.

Dong, Y., Chai, C. S., Sang, G., Koh, J. H. L., \& Tsai, C. C. (2015). Exploring the Profiles and Interplays of Pre-service and In-service Teachers' Technological Pedagogical Content Knowledge (TPACK) in China. Educational Technology \& Society, 18(1), 158-169.

Fraenkel, Wallen \& Hyun (2012). How to Design and Evaluate Research in Education. 8th Ed. New York:McGraw-Hill

Heo, H. (2016). Reflecting teachers' voices: Profiling Competency Standards in ICTenhanced teaching and learning (Republic of Korea). In Diverse Approaches to Developing and Implementing Competency-based ICT Training for Teachers: A Case Study (Vol. 1, pp. 45-65). UNESCO Bangkok.

$\mathrm{Hu}, \mathrm{X}$. (2015). Pre-service teachers' information communication technology (ICT) adoption in preschool settings in Hong Kong. HKU Theses Online (HKUTO).

Jizat, J. E. M. (2012). Investigating ICT-literacy assessment tools: Developing and validating a new assessment instrument for trainee teachers in Malaysia. (Doctoral dissertation, RMIT University).

Kendall, N. (2009). International development education. In International handbook of comparative education (pp. 417-435). Springer Netherlands.

Khan, S. H. (2014). A model for integrating ICT into teacher training programs in Bangladesh based on TPCK. International Journal of Education and Development Using Information and Communication Technology, 10(3), 21-31.

Latchem, C. R., \& Jung, I. (2010). Distance and blended learning in Asia. New York: Routledge.

Lozano, L. M., García-Cueto, E., \& Muñiz, J. (2008). Effect of the number of response categories on the reliability and validity of rating scales. Methodology, 4(2), 73-79.

Majeed, Z. S., \& Yusoff, Z. S. (2015). Are we 'smarter'now? Case study of smart school implementation in a developing nation. Journal of Studies in Education, 5(3), 236258.

Mat-jizat, J. E., Osman, J., Yahaya, R., \& Samsudin, N. (2016). The Use of Augmented Reality (AR) Among Tertiary Level Students: Perception and Experience. Australian Journal of Sustainable Business and Society, 2(1).

Mofarreh, A., \& Ibrahim, Y. (2016). Implementation of ICT policy in secondary schools in Saudi Arabia. (Thesis). University of Wollongong. Retrieved from http://ro.uow.edu.au/cgi/viewcontent.cgi? article=5731\&context=theses

Mugisha, B. (2007). Problems affecting ICT implementation in the curriculum of coreprimary teachers in Kabale District. A case study of Bukinda core primary teachers. (College. Unpublished Bachelors Research), Mbarara University of science and technology, Mbarara,Uganda.

Myers, J. (2014, December 19). Digging into the SAMR Model [Safe, Online Teaching and Learning Platform]. Retrieved April 10, 2015 from /speaks/digging-into-the-samrmodel/

Nordin, H. (2014). Pre-service Teachers' TPACK and Experience of ICT Integration in Schools in Malaysia and New Zealand: A Thesis Submitted in Partial Fulfilment of 
the Requirements for the Degree of Doctor of Philosophy in Education, University of Canterbury, New Zealand (Doctoral dissertation, University of Canterbury).

Pamuk, S. (2012). Understanding preservice teachers' technology use through TPACK framework. Journal of Computer Assisted Learning, 28(5), 425-439. http://doi.org/10.1111/j.1365-2729.2011.00447.x

Sheard, J., \& Carbone, A. (2007). ICT teaching and learning in a new educational paradigm: lecturers' perceptions versus students' experiences. In Proceedings of the Seventh Baltic Sea Conference on Computing Education Research, 88, 109-117. Australian Computer Society, Inc..

Terrace, L. (2003). Development and validation of an international appraisal instrument for assessing the quality of clinical practice guidelines: the AGREE project. Qual Saf Health Care, 12, 18-23.

Trowler, P. R. (2003). Education policy (2nd Ed.). London: Routledge

Varga-Atkins, T. (2016). A study of the role of a technology-enhanced learning implementation group in mediating an institutional VLE minimum standards policy. Research in Learning Technology, 24.

Vedung, E. (1998). Policy Instruments: Typologies and Theories. In M. BemelmansVidec, R. C. Rist \& E. Vedung (Eds.), Carrots, Sticks, and Sermons: Policy Instruments and Their Evaluation. New Brunswick, New Jersey: Transaction Publishers.

Waycott, J., Bennett, S., Kennedy, G., Dalgarno, B., \& Gray, K. (2010). Digital divides? Student and staff perceptions of information and communication technologies. Computers \& education, 54(4), 1202-1211.

Zaki, M., \& Zahilah, F. (2013). ICT and internet usage in early childhood education: a comparative study of Australian and Malaysian teachers' beliefs and current practices (Masters Dissertation). Retrieved from http://eprints.qut.edu.au/63895/1/Filzah\%20Zahilah_Mohamed\%20Zaki_Thesis.pdf 